\title{
Effect of Drying Temperatures and Aids on Polyphenol Content, Antioxidant Activity, and $\beta$ Glucosidase Enzyme Inhibition Activity of Powder Stylissa flexibilis
}

\author{
Dang Xuan Cuong ${ }^{1, *}$, Nguyen Thi Phuong Hien ${ }^{2}$ \\ ${ }^{1}$ Organic Matterial from Marine Resource, Nhatrang Institute of Technology Application and Research, Vietnam Academic of Science and \\ Technology, Nha Trang, Vietnam \\ ${ }^{2}$ Faculty of Food Technology, Nha Trang University, Nha Trang, Vietnam
}

Email address:

cuong_mails@yahoo.com.vn (D.X.Cuong),phuonghiensanest@yahoo.com (N. T. P. Hien)

${ }^{*}$ Corresponding author

\section{To cite this article:}

Dang Xuan Cuong, Nguyen Thi Phuong Hien. Effect of Drying Temperatures and Aids on Polyphenol Content, Antioxidant Activity, and $\beta$ Glucosidase Enzyme Inhibition Activity of Powder Stylissa flexibilis. World Journal of Food Science and Technology. Special Issue: Marine Bio-Polymer: Bio-Activity, Extraction and Application. Vol. 4, No. 2, 2020, pp. 46-52. doi: 10.11648/j.wjfst.20200402.15

Received: March 17, 2020; Accepted: April 2, 2020; Published: April 29, 2020

\begin{abstract}
Sponge Stylissa flexibilis is Porifera belong to a medicine animal group in the Vietnam sea, contains numerous valuable bioactive substances. The study focused on the impact of spray-drying input temperatures $\left(90^{\circ} \mathrm{C}, 100^{\circ} \mathrm{C}, 110^{\circ} \mathrm{C}\right.$, and $120^{\circ} \mathrm{C}$ ) and aids (Maltodextrin, saccharose: maltodextrin mixture $(1: 1, \mathrm{w} / \mathrm{w}$ and $\left.1: 2, \mathrm{w} / \mathrm{w})\right)$ on the physical-chemical properties (moisture content, solubility, and polyphenol content), antioxidant activities (mechanism $\mathrm{Mo}^{6+}$ and $\mathrm{Fe}^{3+}$ ), and inhibition enzyme $\beta$ Glucosidase of sponge extract powder. The sponge was collected from the sponge in May 2017 in the Ninh Thuan sea. The results showed the polyphenol content, total antioxidant activity, reducing power activity, and $\beta$ Glucosidase enzyme inhibition activity was affected by the temperature and aids of the drying process and got the highest value of $77.692 \pm 2.025 \mathrm{mg}$ phloroglucinol equivalent $/ 100 \mathrm{~g} \mathrm{DW}, 98.526 \pm 1.997 \mathrm{mg}$ ascorbic acid equivalent $/ 100 \mathrm{~g} \mathrm{DW}$, $28.945 \pm 0.754 \mathrm{mg} \mathrm{FeSO}{ }_{4}$ equivalent $/ 100 \mathrm{~g} \mathrm{DW}$, and $75.38 \pm 2.516 / 100 \mu \mathrm{g} / \mathrm{ml}$ was at $90^{\circ} \mathrm{C}$, respectively, compared to the others. The moisture of powder was a negative-correlation to the increase of drying temperature. All the powder dissolved fully in the water. Polyphenol content and bioactivities (antioxidant activity, $\beta$ Glucosidase enzyme inhibition activity) was a strong correlation with each other $\left(\mathrm{R}^{2}>0.8\right)$ and a positive-correlation to drying temperature. The suitable condition for drying of active polyphenol powder was at $90^{\circ} \mathrm{C}$ and $10 \%$ of maltodextrin. Active polyphenol powder can be useful for applicating into functional foods and pharmaceutics.
\end{abstract}

Keywords: Antioxidant Activity, Marine Sponge, Polyphenol, Solubility, Sponge Powder, Spray-Drying, Glucosidase Enzyme

\section{Introduction}

Marine sponge, a porifera animal, is mostly grown in numerous regions in the world from the deep sea $(8,500 \mathrm{~m})$ to the coast $[1,2]$ with over 9,000 marine species [3], for example, Mediterranean, America, Cuba, the Caribbean [4], Vietnam, Thailand, Cambodia, and Singapore [5]. Every year hundreds of new compounds are detected in a marine sponge, and nowadays, more than 5,300 different metabolites were noticed [6] with their activity, such as anti-inflammatory, anticancer, immune, anti-HIV, antimalarial, antibiotic, antifouling [3, 7-9], antioxidant [10-13], acetylcholinesterase enzyme inhibition, and glucosidase enzyme inhibition [11, 13]. The metabolites from sponge are diverse, for example, polyphenol $[10,11]$, lipid groups, quinone, terpenoid, alkaloid, halogen derivatives, peptide groups [3]. Almost previous studies on sponges are the cultivation, the metabolites isolation, and the bioactive evaluation from the sponge. Some studies noticed on the extraction [14] and the purification [15] of active polyphenol from the sponge, but no notices on spray drying of active polyphenol from marine sponge extract. 
Spray drying is useful in the industry of the pharmaceutics, food, and chemistry, help moisture decrease of products, bacterial degradation and extend of storage time for the product, and fit for different types of materials.

Stylissa flexibilis distributes numerous regions in the world, for example, Vietnam, and possesses value bioactive ingredients with different activities $[10,11,14,16]$. At the same time, the active polyphenol of marine sponge Stylissa flexibilis is temperature sensitivity.

Therefore, the study focused on the effect of the input temperature and aids (kind and ratio) of spray drying process on the polyphenol content, antioxidant activity, and $\beta$ glucosidase enzyme inhibition, and the evaluation of physical characterization of powder (moisture and water solubility).

\section{Material and Methods}

\subsection{Sample Preparation}

\subsubsection{Extract Preparation for Spray Drying}

Sponge Stylissa flexibilis collected from Hon Mot island in Nha Trang Bay, Khanh Hoa province, Vietnam, were transported to the laboratory in the day at the temperature under $4^{\circ} \mathrm{C}$. Dirt and any impurities on the sponge were washed under running tap. They were ground into small pieces by nitrogen liquid and stored at $-20^{\circ} \mathrm{C}$ for further study. To produce an extract by the Soxhlet technique of extraction at the temperature of $60^{\circ} \mathrm{C}$ for 80 minutes with the ratio of solvent and material $(30 / 1(\mathrm{v} / \mathrm{w}))$ and using methanol as extraction solvent. After extraction, filtering the mixture was with Whatman no. 1 paper, and the extract volume decrease was to one part three volume by the concentration at $40^{\circ} \mathrm{C}$. The concentrated extract storage was at $4^{\circ} \mathrm{C}$ until further study.

\subsubsection{Solution Preparation of Aid for Spray Drying}

Various aid solutions vortexed with sponge extracts using Wisd Homogenizer (Wisd, Frankfurt, Germany) were prepared in turn by dissolving maltodextrin (MD); maltodextrin: saccharose $(1: 1)$ or maltodextrin and saccharose $(2: 1)$ powder mixture into $50^{\circ} \mathrm{C}$ distilled water at $10: 3(\mathrm{v} / \mathrm{w})$ ratio. Before spray drying, the sponge extract and aid solutions were vortexed according to the ratio of $1: 1(\mathrm{v} / \mathrm{v})$ at $3.000 \mathrm{rpm}$. Collecting the antioxidant polyphenol powder was by the spray drying of the mixture on a Lab Plant SD06 spray dryer (Keison, Chelmsford, UK), and the powders storage at $4^{\circ} \mathrm{C}$ for further analysis.

\subsubsection{Extract Preparation from Spray Drying Powder}

The sponge powder was vortexed to $96 \%$ methanol according to the ratio of solvent to powder $(50 / 1, \mathrm{v} / \mathrm{w})$ (Merck, Darmstadt, Germany) at room temperature for 30 min in the dark. The mixture centrifugation was then at 5000 rpm at $4^{\circ} \mathrm{C}$ for $15 \mathrm{~min}$ (Z326 K, Hermle Labortechnik $\mathrm{GmbH}$, Wehingen, Germany) for collecting supernatant which stored at $4{ }^{\circ} \mathrm{C}$ for the analysis of polyphenol content and antioxidant activities.

\subsection{Study on the Effect of Spray Drying Temperature and Aids on the Powder Properties}

\subsubsection{Study on the Effects of Aid Kind on the Powder Properties}

To find the effects of aids on physical-chemical properties and antioxidant activities of the sponge powder by spray drying a mixture of sponge extract and aids was at the temperatures of $110^{\circ} \mathrm{C}$ with the feed flow rate of 10 $\mathrm{mL} /$ minutes, pump pressure of 0.8 bar and output temperature of $45^{\circ} \mathrm{C}$. Maltodextrin content was $15 \%$ of the mixture. Various aids included maltodextrin (MA), the mixture of maltodextrin: saccharose at ratio 2:1 (w/w) (MAS21) and 1:1 (w/w) (MAS11).

\subsubsection{Study on the Effects of Aid Ratio on the Powder Properties}

To evaluate effects of spray-drying temperature on physical-chemical properties and antioxidant activities of the sponge powder by spray drying a mixture of sponge extract and maltodextrin was at temperatures of $110^{\circ} \mathrm{C}$ with the feed flow rate of $10 \mathrm{~mL} /$ minutes, pump pressure of 0.8 bar and output temperature of $45^{\circ} \mathrm{C}$. Maltodextrin content was varied from $5 \%, 10 \%, 15 \%$ and $20 \%$ of the mixture.

\subsubsection{Study on the Effects of Temperature on the Powder Properties}

Evaluating effects of spray-drying temperature on physical-chemical properties and antioxidant activities of the sponge powder by spray drying a mixture of sponge extract and maltodextrin was at different temperatures of $90^{\circ} \mathrm{C}$, $100^{\circ} \mathrm{C}, 110^{\circ} \mathrm{C}$, and $120^{\circ} \mathrm{C}$ with the feed flow rate of 10 $\mathrm{mL} /$ minutes, pump pressure of 0.8 bar and output temperature of $45^{\circ} \mathrm{C}$. Maltodextrin content was $10 \%$ of the mixture.

\subsection{Determination of Physical Chemistry Characterization}

\subsubsection{Determination of Moisture Content}

Determining moisture contents of the powders were according to the AOAC method 976.05.

In detail, drying samples were at $105^{\circ} \mathrm{C}$ until constant weight, named final weight and calculating the moisture contents were as follows.

Moisture content $(\%)=\frac{\text { Initial weight }- \text { final weight }}{\text { Initial weight }} \times 100 \%$

\subsubsection{Determination of Water Solubility of Powder}

Determining the solubility of the powders was according to the description of Takasi et al. [20] with some slight modifications. The first, dissolving $0.1 \mathrm{~g}$ of sample was into 1 $\mathrm{mL}$ of distilled water at $30^{\circ} \mathrm{C}$ and centrifuged at $9500 \mathrm{rpm}$ for $10 \mathrm{~min}$. Drying the supernatant was then to reach a moisture content of the initial sample at $105^{\circ} \mathrm{C}$, named the dissolve weight. The final, using the dissolve weight for the calculation of the solubility of the samples, shown in according to the following equation.

The water solubility ofpowder $(\%)=\frac{\text { Dissolve weight }}{\text { Initial weight }} \times 100 \%$ 


\subsubsection{Determination of Polyphenol Content of Powder}

The quantification of polyphenol content was according to the description of Swanson et al. In brief, adding $0.5 \mathrm{~mL}$ of $10 \%$ Folin-Ciocalteau (Sigma-Aldrich, Germany) was into $300 \mathrm{~mL}$ extract, vortexed and kept for $5 \mathrm{~min}$. After that, adding $2 \mathrm{~mL}$ of $5 \%$ sodium carbonate solution (Merck, Germany) into the mixture, and kept the mixture for $90 \mathrm{~min}$ at room temperature. The absorbance measurement of the mixture was at a wavelength $750 \mathrm{~nm}$ on a UV-visible spectrophotometer machine and using gallic acid (Merck, Germany) as the standard.

\subsection{Evaluation of Biological Activity}

\subsubsection{Evaluation of Total Antioxidant Activity}

Total antioxidant activity was determined basing on the absorbance measurement of the metabolism reaction of $\mathrm{Mo}^{6+}$ to $\mathrm{Mo}^{5+}$ at the wavelength of $695 \mathrm{~nm}$ with ascorbic acid standard [17].

\subsubsection{Evaluation of Reducing Power Activity}

Reducing power activity was determined to base on the absorbance measurement of $\mathrm{Fe}^{2+}$ at $655 \mathrm{~nm}$ that was formed from the metabolism of $\mathrm{Fe}^{3+}$ to $\mathrm{Fe}^{2+}$, with $\mathrm{FeSO}_{4}$ standard. [18].

\subsubsection{Evaluation of $\beta$ Glucosidase Inhibition Activity}

The extract dissolved into phosphate buffer, and then added $0.1 \mathrm{~mL}$ enzyme, vortex, and kept for 5 minutes at $37^{\circ} \mathrm{C}$. Then add $0.1 \mathrm{ml}$ of the substrate solution, mix well, incubate at $37^{\circ} \mathrm{C}$ for 25 minutes, finally add $1.5 \mathrm{ml}$ of $0.1 \mathrm{M} \mathrm{Na}_{2} \mathrm{CO}_{3}$ solution and measure the optical density at $405 \mathrm{~nm}$. Determination of the ability of enzyme inhibition based on the optical density, compared to the control sample (the control sample similar the sample but replacing the extract by the dissolving solvent of the extract) [19].

\subsection{Data Analysis}

All the experiments were triplication and data presentation under mean \pm standard deviations. Analysis of ANOVA, regression, and descriptive statistics were by using MS. Excel 2010. To remove unnormal value was by the method of Duncan.

\section{Results and Discussion}

\subsection{Effects of Different Spray-Drying Aids on Sponge Powder Characterization}

\subsubsection{Polyphenol Content, Moisture, and Water Solubility}

The dry aids affected the polyphenol content of powder $(\mathrm{p}<$ 0.05). The highest polyphenol content of powder was with the maltodextrin aids. The polyphenol content of powder was arranged in the decreasing order as follows: $15 \%$ of MA, 15\% of MAS21, and $15 \%$ of MAS11. The polyphenol content of powder using MAS11 was 0.93 and 0.97 times of MAS2 1 and MA, respectively. The saccharose ratio in drying aids increased by $33.33 \%$ (Figure 1), polyphenol content of powder was decreased by about $3 \%$. The moisture of polyphenol powder was in the range of 6.7 and $7.8 \% \mathrm{DW}$, corresponding to MA and MAS11, respectively, and all various powder dissolved fully in the water for 5 minutes.

\subsection{2. $\mathrm{Mo}^{6+}$ Metabolism Activity}

The $\mathrm{Mo}^{6+}$ metabolism activity of different powders were significant differences $(\mathrm{p} \leq 0.05)$ and possessed the highest value of $96.523 \pm 2.317$ (mg ascorbic acid equivalent/g DW) with MA. In contrast, the $\mathrm{Mo}^{6+}$ metabolism activity of MAS 11 powder was the lowest with $90.517 \pm 2.101$ (mg ascorbic acid equivalent/g DW) (Figure 1). The $\mathrm{Mo}^{6+}$ metabolism activity of MAS21 powder was 1.03 times of MAS11 powder. However, an insignificant difference in the $\mathrm{Mo}^{6+}$ metabolism activity occurred between MA and MAS21, and between MAS21 and MAS11. The maltodextrin ratio in drying aids increased by double in comparison to the saccharose ratio, $\mathrm{Mo}^{6+}$ metabolism activity of powder was increased by $2.95 \%$. A good correlation between polyphenol content and $\mathrm{Mo}^{6+}$ metabolism activity was showed through ANOVA analysis $\left(\mathrm{R}^{2}>0.9\right)$.

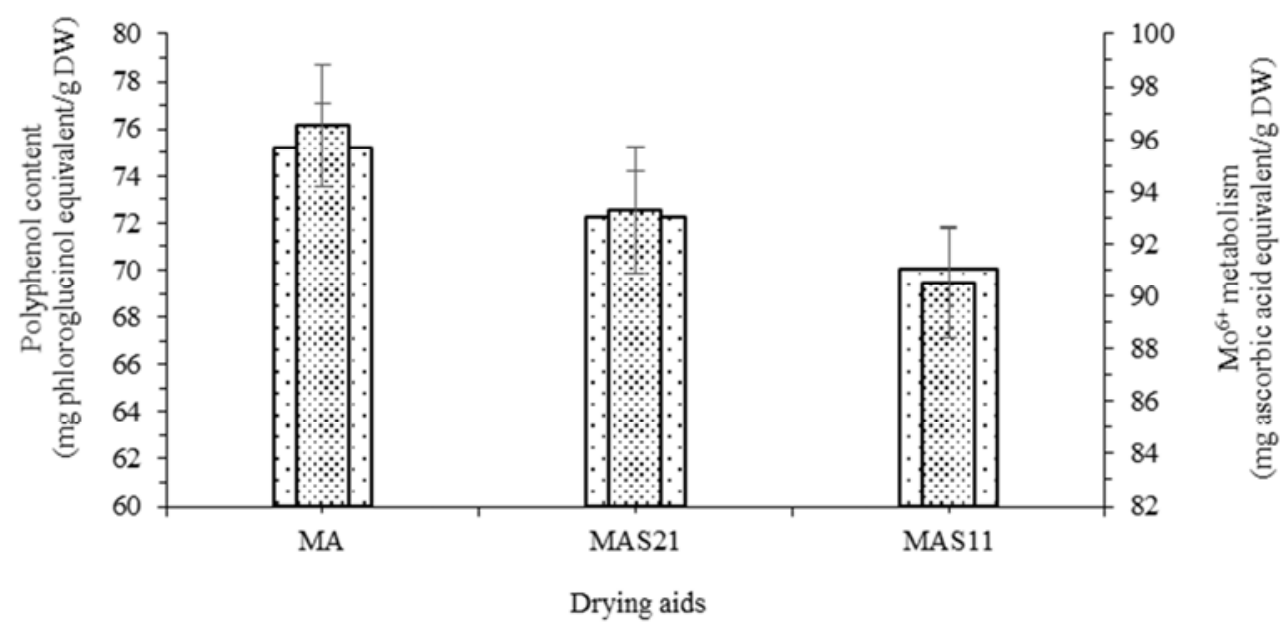

口Polyphenol content QMo6+ metabolism

Figure 1. Effect of spray-drying aids on polyphenol content and total antioxidant activity of powder. 


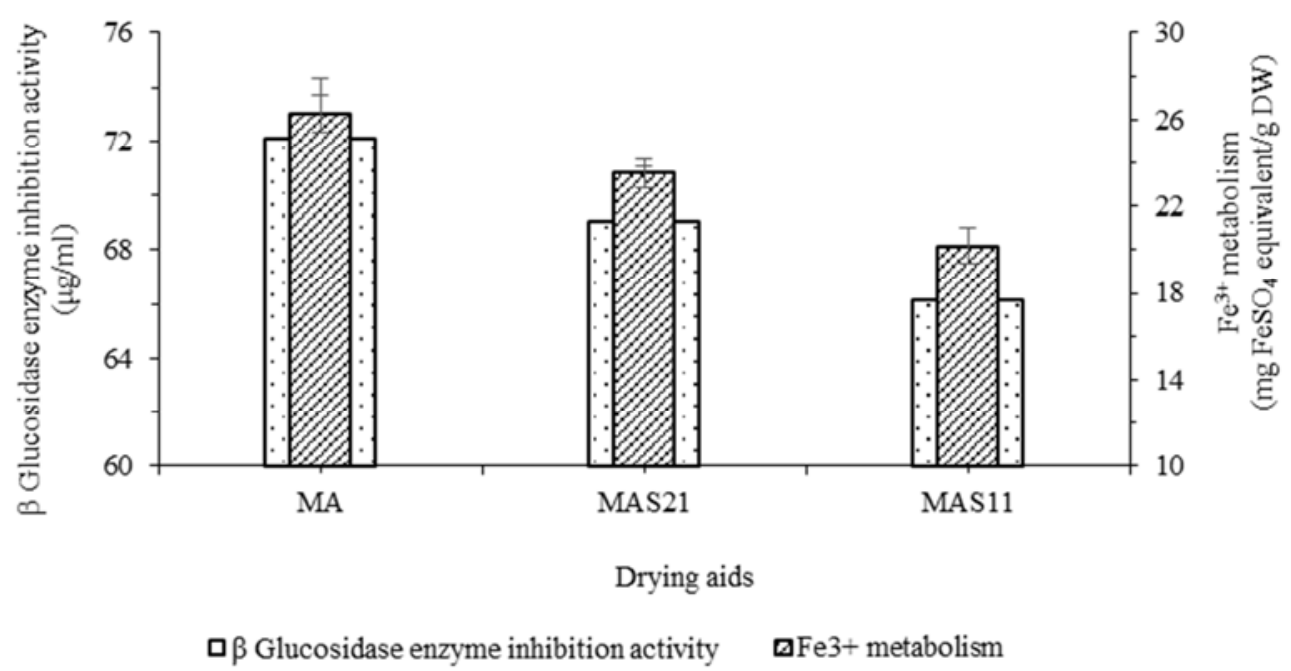

Figure 2. Effect of spray-drying aids on reducing power activity and $\beta$ glucosidase enzyme inhibition activity of powder.

\subsection{3. $\mathrm{Fe}^{3+}$ Metabolism Activity}

There was a significant difference in $\mathrm{Fe}^{3+}$ metabolism activity of sponge powders preparing from different carriers $(\mathrm{p}<0.05)$. MA exhibited the highest $\mathrm{Fe}^{3+}$ metabolism activity (26.255 $\pm 0.873 \mathrm{mg} \mathrm{FeSO}{ }_{4}$ equivalent/g DW) (Figure 2). The followings were MAS21 (23.515 $\pm 0.689 \mathrm{mg} \mathrm{FeSO}_{4}$ equivalent/g DW) and MAS11 (20.188 $\pm 0.837 \mathrm{mg} \mathrm{FeSO} 4$ equivalent/g DW). The maltodextrin ratio in drying aids decreased by $33.33 \%, \mathrm{Fe}^{3+}$ metabolism activity of powder was decreased by $14.15 \%$. The $\mathrm{Fe}^{3+}$ metabolism activity was an insignificant difference in MA and MAS21, and MAS21 and MAS11. Polyphenol content and $\mathrm{Fe}^{3+}$ metabolism activity had a good correlation $\left(\mathrm{R}^{2}>0.9\right)$.

\subsubsection{B glucosidase Enzyme Inhibition Activity}

All polyphenol powders from sponge Stylissa flexibilis exhibited $\beta$ glucosidase enzyme inhibition activity and was affected by the drying aids style $(p<0.05) . \beta$ glucosidase enzyme inhibition activity had a similar trend for antioxidant activity and polyphenol content, was arranged in the increasing order as follows: MAS11, MAS21, and MA. $\beta$ glucosidase enzyme inhibition activity of MA (72.116 \pm $2.191 \mu \mathrm{g} / \mathrm{ml}$ ) was 1.09 and 1.05 times of MAS11 and MAS21, respectively (Figure 2). The difference in $\beta$ glucosidase enzyme inhibition activity of MA and MAS21, and MAS2 1 and MAS11 were not significant. Polyphenol content had a good correlation $\left(\mathrm{R}^{2}>0.9\right)$ for $\beta$ glucosidase enzyme inhibition activity.

\subsection{Effects of Drying Aids Ratio on Sponge Powder Characterization}

\subsubsection{Polyphenol Content, Moisture, and Water Solubility}

The difference in the aids ratio caused the change of the polyphenol content in the powder that varied in the range of $72.262 \pm 1.976$ and $76,209 \pm 1.734 \mathrm{mg}$ phloroglucinol equivalent/g DW and exhibited the highest value at $10 \%$ of aids (Figure 3). The followings were $5 \%, 20 \%$, and $15 \%$ of aids.

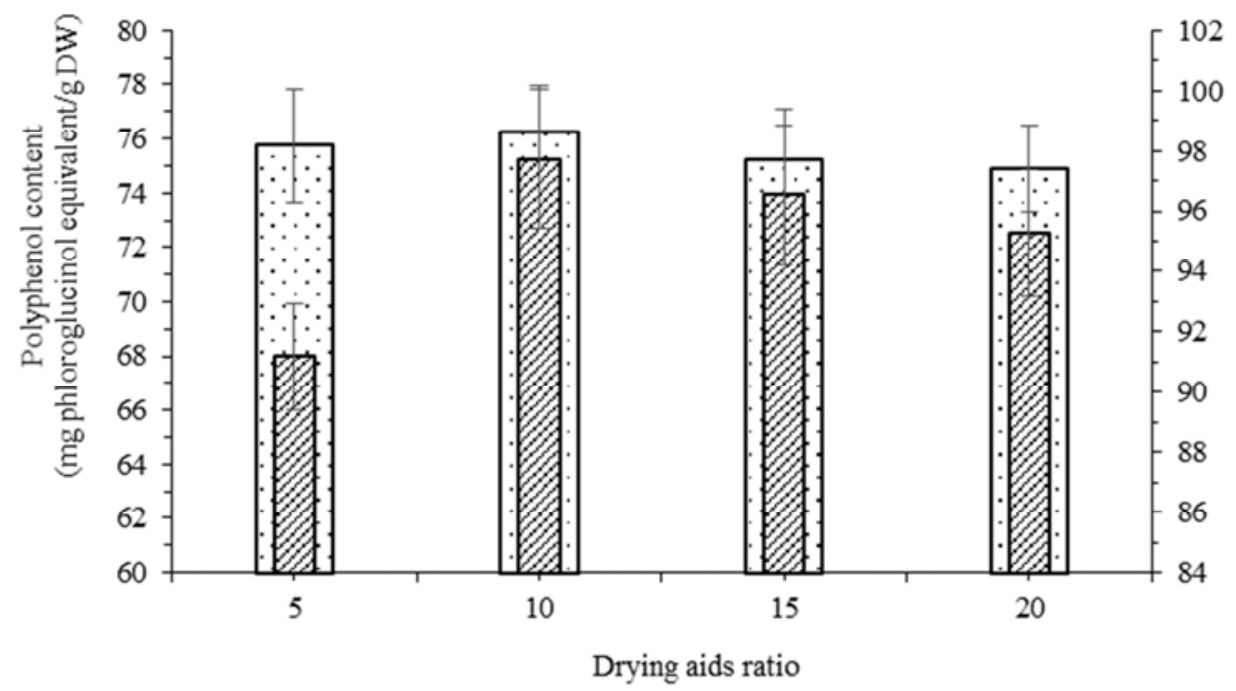

๑Polyphenol content $\mathbf{\square M O 6 +}$ metabolism

Figure 3. Effect of drying aids ratio on polyphenol content and total antioxidant activity of powder. 


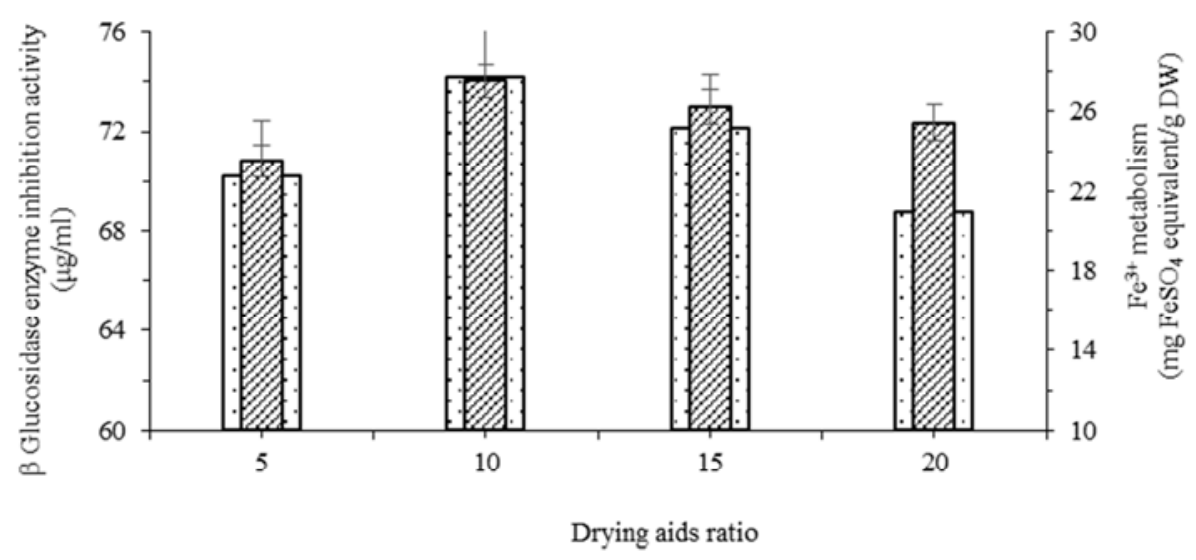

口 $\beta$ Glucosidase enzyme inhibition activity $\quad \mathbf{a F e} 3+$ metabolism

Figure 4. Effect of drying aids ratio on reducing power activity and $\beta$ glucosidase enzyme inhibition activity of powder.

The aids ratio decreased from $20 \%$ to $5 \%$, the polyphenol content of powder changed according to the model of level 2 with a maximum peak at $10 \%$ of aids. The significant difference in polyphenol content at $10 \%$ and $15 \%$ of aids was clear $(p<0.05)$. The difference in the moisture of various powders was insignificant $(\mathrm{p}<0.05)$. The full dissolving of all polyphenol powders into the water for 5 minutes was not different.

\subsection{2. $\mathrm{Mo}^{6+}$ Metabolism Activity}

The $\mathrm{Mo}^{6+}$ metabolism activity of active polyphenol powders was depended on the aids ratio $(p \leq 0.05)$ and was from $91.186 \pm 1.755$ to $97.727 \pm 2.318 \mathrm{mg}$ ascorbic acid equivalent/g DW. The $\mathrm{Mo}^{6+}$ metabolism activity of active polyphenol powders got the highest and lowest value at $5 \%$ and $10 \%$ of drying aids, respectively. The model of level 2 with the maximum peak at $10 \%$ of drying aids was shown, as in Figure 3, and similar observation for the changing model of polyphenol content. $\mathrm{Mo}^{6+}$ metabolism activity and polyphenol content was a good correlation according to the change of drying aids $\left(\mathrm{R}^{2}>0.9\right)$.

\subsection{3. $\mathrm{Fe}^{3+}$ Metabolism Activity}

$\mathrm{Fe}^{3+}$ metabolism activity of polyphenol powder was from $91.186 \pm 1.755$ to $97.727 \pm 2.318 \mathrm{mg} \mathrm{FeSO}{ }_{4}$ equivalent $/ \mathrm{g}$ DW and its highest value at $10 \%$ of drying aids. The followings were at $20 \%, 15 \%$, and $5 \%$ of drying aids. $\mathrm{Fe}^{3+}$ metabolism activity of polyphenol powder at $15 \%$ and $20 \%$ of drying aids corresponded to 95.44 and $97.5 \%$, compared to $10 \%$ of drying aids (Figure 4 ). $\mathrm{Fe}^{3+}$ metabolism activity of polyphenol powder was a positive correlation to polyphenol content and impacted by the drying aids ratio with the changing trend according to the non-linear model of level 2 having the maximum peak.

\subsubsection{B glucosidase Enzyme Inhibition Activity}

$\beta$ glucosidase enzyme inhibition activity is also not an exception when it was affected by the drying temperature similar to polyphenol content and antioxidant activity $(\mathrm{p}<$ 0.05 ). The changing trend of $\beta$ glucosidase enzyme inhibition activity was like antioxidant activity and polyphenol content with the highest and the lowest value at $90^{\circ} \mathrm{C}(75.38 \pm 2.516$ $\mu \mathrm{g} / \mathrm{ml})$ and $120^{\circ} \mathrm{C}(73.116 \pm 2.284 \mu \mathrm{g} / \mathrm{ml})$, respectively. $\beta$ glucosidase enzyme inhibition activity of powder at $110^{\circ} \mathrm{C}$ and $110^{\circ} \mathrm{C}$ was $98.45 \%$ and $99.7 \%$, compared to $90^{\circ} \mathrm{C}$ (Figure 4). $\beta$ glucosidase enzyme inhibition activity of powder drying from $90^{\circ} \mathrm{C}$ to $110^{\circ} \mathrm{C}$ was an insignificant difference $(p>0.05)$. Polyphenol content was positively proportional to $\beta$ glucosidase enzyme inhibition activity $\left(\mathrm{R}^{2}>\right.$ $0.9)$.

\subsection{Effects of Spray-Drying Temperatures on Sponge Powder Characterization}

\subsubsection{Polyphenol Content, Moisture, and Water Solubility}

The polyphenol content of powder was affected by the drying temperature $(\mathrm{p}<0.05)$ and was from $70.035 \pm 1.802$ to $77.692 \pm 2.025 \mathrm{mg}$ phloroglucinol equivalent/g DW. When the temperature decreased from $120^{\circ} \mathrm{C}$ to $90^{\circ} \mathrm{C}$, the polyphenol content of powder increased. The polyphenol content of powder at $120^{\circ} \mathrm{C}$ was $92 \%, 90.97 \%$, and $90.22 \%$, compared to at $110^{\circ} \mathrm{C}, 100^{\circ} \mathrm{C}$, and $90^{\circ} \mathrm{C}$, respectively (Figure 5). The insignificant difference in polyphenol content occurred at various temperatures of drying, except for $120^{\circ} \mathrm{C}$. The water solubility of polyphenol powders drying at various temperatures was full. The moisture of polyphenol powders varied from 5.5 to $8.3 \% \mathrm{DW}$, corresponding to at $120^{\circ} \mathrm{C}$ to $90^{\circ} \mathrm{C}$, respectively.

\subsection{2. $\mathrm{Mo}^{6+}$ Metabolism Activity}

The $\mathrm{Mo}^{6+}$ metabolism activity of different powders was affected by the drying temperature $(\mathrm{p} \leq 0.05)$ and got the highest value $(98.526 \pm 1.997 \mathrm{mg}$ ascorbic acid equivalent $/ \mathrm{g}$ DW) at $90^{\circ} \mathrm{C}$. In contrast, the $\mathrm{Mo}^{6+}$ metabolism activity was the lowest $(95.008 \pm 1.926 \mathrm{mg}$ ascorbic acid equivalent $/ \mathrm{g}$ DW) at $120^{\circ} \mathrm{C}$. The $\mathrm{Mo}^{6+}$ metabolism activity at $120^{\circ} \mathrm{C}$ was 0.97 and 0.96 times, compared to at $110^{\circ} \mathrm{C}$ and $100^{\circ} \mathrm{C}$, respectively (Figure 5). Similar observation for polyphenol content, the significant difference in $\mathrm{Mo}^{6+}$ metabolism activity only occurred at $120^{\circ} \mathrm{C}$ in comparison to other drying temperature. Polyphenol content and $\mathrm{Mo}^{6+}$ metabolism activity was a good correlation under the effect of drying 
temperature $\left(\mathrm{R}^{2}>0.9\right)$.

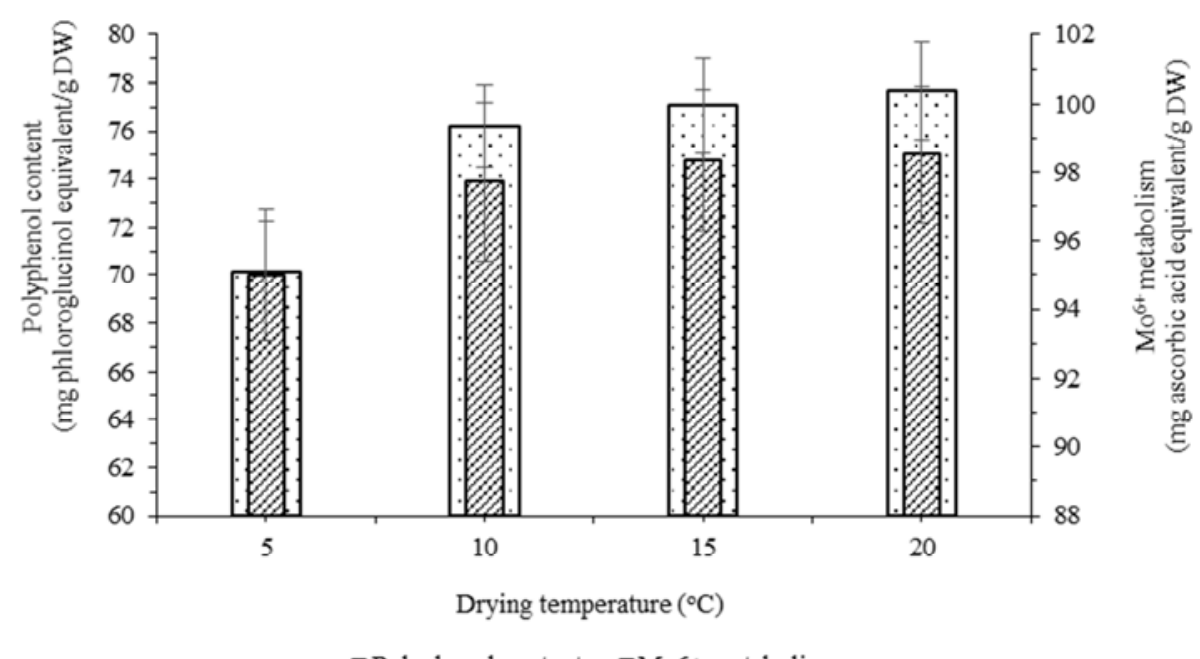

Figure 5. Effect of drying temperature on polyphenol content and total antioxidant activity of powder.

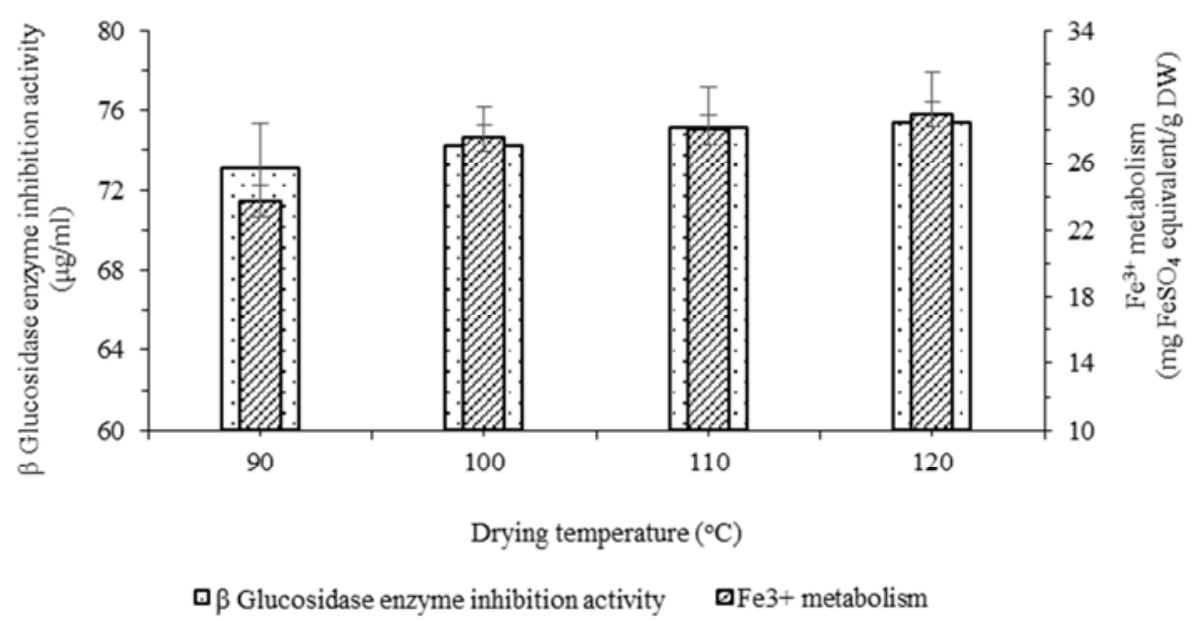

Figure 6. Effect of drying temperature on reducing power activity and $\beta$ glucosidase enzyme inhibition activity of powder.

\subsection{3. $\mathrm{Fe}^{3+}$ Metabolism Activity}

The drying temperature impacted significantly on $\mathrm{Fe}^{3+}$ metabolism activity of sponge powders $(\mathrm{p}<0.05)$ and had the highest $\mathrm{Fe}^{3+}$ metabolism activity $(28.945 \pm 0.754 \mathrm{mg}$ $\mathrm{FeSO}_{4}$ equivalent/g DW) at $90^{\circ} \mathrm{C}$, compared to various drying temperatures. The followings were at $100^{\circ} \mathrm{C}(28.045 \pm$ $0.851), 110^{\circ} \mathrm{C}\left(27.552 \pm 0.832 \mathrm{mg} \mathrm{FeSO}{ }_{4}\right.$ equivalent/g DW), and $120^{\circ} \mathrm{C}\left(23.756 \pm 0.945 \mathrm{mg} \mathrm{FeSO}_{4}\right.$ equivalent/g DW $)$ (Figure 6). Similar $\mathrm{Mo}^{6+}$ metabolism activity, $\mathrm{Fe}^{3+}$ metabolism activity of powder was a good correlation to polyphenol content $\left(\mathrm{R}^{2}>0.9\right)$ and insignificantly different at the drying temperature $90^{\circ} \mathrm{C}, 100^{\circ} \mathrm{C}$, and $110^{\circ} \mathrm{C}$, except for $120^{\circ} \mathrm{C}$.

\subsection{4. $\beta$ glucosidase Enzyme Inhibition Activity}

$\beta$ glucosidase enzyme inhibition activity is also not an exception when it was affected by the drying temperature similar to polyphenol content and antioxidant activity $(\mathrm{p}<0.05)$. The changing trend of $\beta$ glucosidase enzyme inhibition activity was like antioxidant activity and polyphenol content with the highest and the lowest value at $90^{\circ} \mathrm{C}(75.38 \pm 2.516 \mu \mathrm{g} / \mathrm{ml})$ and $120^{\circ} \mathrm{C}(73.116 \pm 2.284 \mu \mathrm{g} / \mathrm{ml})$, respectively (Figure 6). $\beta$ glucosidase enzyme inhibition activity of powder at $110^{\circ} \mathrm{C}$ and $110^{\circ} \mathrm{C}$ was $98.45 \%$ and $99.7 \%$, compared to $90^{\circ} \mathrm{C}$. $\beta$ glucosidase enzyme inhibition activity of powder drying from $90^{\circ} \mathrm{C}$ to $110^{\circ} \mathrm{C}$ was an insignificant difference $(\mathrm{p}>0.05)$. Polyphenol content was positively proportional to $\beta$ glucosidase enzyme inhibition activity $\left(R^{2}>0.9\right)$.

\section{Conclusion}

In general, the inlet temperatures and aids (kinds and ratio) of the spray-drying process significantly affected the moisture content, polyphenol content, antioxidant activity (total antioxidant activity and reducing power), and $\beta$ glucosidase enzyme inhibition activity of marine sponge extract powder Stylissa flexibilis, except for water solubility. The increase of spray-drying temperature caused by the decrease of moisture content, polyphenol content, antioxidant activity, and $\beta$ glucosidase enzyme inhibition activity, and the suitable drying temperature of $90^{\circ} \mathrm{C} .10 \%$ of maltodextrin was the best use for 
the spray drying process, compared to the mixture of maltodextrin and saccharose. Polyphenol content had relatively high antioxidant activity and $\beta$ glucosidase enzyme inhibition activity. It is suggested marine sponge extract powder Stylissa flexibilis containing high polyphenol content with high antioxidant activity, high $\beta$ glucosidase enzyme inhibition activity, good water solubility, and low moisture content can be useful into applicating for functional foods and pharmaceutics.

\section{Acknowledgements}

The author thanks Tran Khac Tri Nhan, Dang Thi Thanh Tuyen (Faculty of Food Technology, Nha Trang University), Lam Van Tu (Faculty of Fisheries Technology, Ho Chi Minh University of Food Industry), Tran Mai Duc, Tran Quang Thai (Nha Trang Institute of Technology Application and Research, VAST), and Thai Minh Quang (Oceanography Institute, VAST) for helping.

\section{References}

[1] John N. H. and Rob, v. S., Systema porifera: a Guide to the classification of sponges, New York: Kluwer Academic/Plenem Publishers, 2002, pp. 1-4.

[2] Rob W. V. S., et al. (2012). Global Diversity of Sponges (Porifera). PLoS One, 7 (4): e35105.

[3] Phan V. K., et al. (2019). The chemical constituents and biological activity of some sponges in Northern Vietnam: A review. Vietnam J Chem, 57 (3): 261-271.

[4] Duckworth A. R., C N Battershill and P, R. B. (1997). Influence of explant procedures and environmental factors on culture success of three sponges. Aquaculture, 156 251-267.

[5] Ton T. H. D., Georg, S., Nguyen, T. K. C., Hauke, S. and Detmer, S. (2018). Archaeal and bacterial diversity and community composition from 18 phylogenetically divergent sponge species in Vietnam. Peer J, 6 e 4970.

[6] Faulkner D. (2002). Marine natural products. Nat Prod Rep, 19 $1-48$.

[7] Gordaliza M. (2010). Review: cytotoxic terpene quinones from marine sponges. Mar Drugs, 8 2849-2870.

[8] Blunt J., Copp, B., Hu, W.-P., Munro, M., Northcote, P. and Prinsep, M. (2009). Marine natural products. Nat Prod Rep, 26 170-244.

[9] Zhu Y., Shen, J., Wang, H., Cosentino, L. and Lee, K. (2001).
Synthesis and anti-HIV activity of oleanolic acid derivatives. Bioorg Med Chem Lett, 11 3115-3118.

[10] Dang X. C., et al. (2019). Polyphenol content, phytochemistry compositions and antioxidant activity of different extracts from marine sponge Aaptos suberitoides grown in Nhatrang bay, Vietnam Int J Pharm Pharm Sci, 11 (9): 80-86.

[11] Dang X. C., Vu, N. B., Tran, K. T. N., Nguyen, T. P. H. and Thai, M. Q. (2018). Species composition and bioactive substances of sponge in central southern area, vietnam. Fisheries Journal of Technology and Science, 3 17-25.

[12] Mohamed S., Howaida, I. A. A., Amal, Z. H., Hanan, F. A. and Mohamed, A. G. (2012). Chemical characterization, antioxidant and inhibitory effects of some marine sponges against carbohydrate metabolizing enzymes. Org Med Chem Lett, 2 (1): 30.

[13] Faten K. A. E.-H., Mohamed, S. A.-A., Kamel, H. S., Zeinab, A. E.-S. and Laila, S. I. (2015). Antioxidant, acetylcholinesterase and $\alpha$-Glucosidase potentials of metabolites from the marine fungus Aspergillus unguis RSPG_204 associated with the sponge (Agelas sp.). Int $J$ Pharm Sci Rev Res, 30 (1): 272-278.

[14] Dang X. C., Vu, N. B., Nguyen, T. P. H. and Dang, T. T. T. (2019). Total polyphenol content, antioxidant and inhibition enzyme $\beta$ - glucosidase activities of sponge Stylissa $s p$. Agriculture Journal and Rural Development, 19 87-94.

[15] Tran K. T. N., Vu, N. B. and Dang, X. C. (2017). Initial purification of polyphenol with antioxidant activity from sponge Aaptos suberitoides Brøndsted (1934) Fisheries Journal of Technology and Science, 4 64-71.

[16] Hung L., et al. (2018). Purification, characterization and biological effect of lectin from the marine sponge Stylissa flexibilis (Lévi, 1961). Comp Biochem Physiol B Biochem Mol Biol, 216 32-38.

[17] Prieto P., Pineda, M. and Aguilar, M. (1999). Spectrophotometric quantitation of antioxidant capacity through the formation of a phosphomolybdenum complex: specific application to the determination of vitamin E. Anal Biochem, 269 (2): 337-341.

[18] Qin Y. Z., Robert, M. H., Jodi, L. E., Roberta, R. H. and Carl, L. K. (2002). Antioxidative activities of oolong tea. J Agric Food Chem, 50 (23): 6929-6934.

[19] Verma, N., Behera, B. C. and Sharma, B. O. (2012). Glucosidase inhibitory and radical scavenging properties of lichen metabolites salazinic acid, sekikaic acid and usnic acid. Hacettepe J. Biol. \& Chem, 40 (1): 7-21.

[20] Takasi, S. and Seibi, P. A. (1988) Paste and gel properties of prime corn and wheat starches with and without nitric liquids. Cereal Chem, 65 474-483. 